\title{
Flooding Tolerance of Soybean [Glycine max (L.) Merr.] Germplasm from Southeast Asia under Field and Screen-House Environments
}

\author{
Tara T.VanToai ${ }^{1}$,*, Tran Thi Cuc Hoa ${ }^{2}$, Nguyen Thi Ngoc Hue ${ }^{2}$, Henry T. Nguyen ${ }^{3}$, J. Grover \\ Shannon ${ }^{3,4}$ and Mohammed Atiqur Rahman ${ }^{5}$
}

${ }^{1}$ USDA-ARS, Soil Drainage Research Unit, Columbus, Ohio. ${ }^{2}$ Cuu Long Delta Rice Research Institute, Cantho, Vietnam. ${ }^{3}$ National Center for Soybean Biotechnology and Division of Plant Sciences, University of Missouri, Columbia, Missouri. ${ }^{4}$ University of Missouri, Delta Center, Portageville, Missouri. ${ }^{5}$ Office of Information Technology, the Ohio State University, Columbus, Ohio

\begin{abstract}
Soybean (Glycine $\max$ L. Merr.) cultivars from the U.S. are generally intolerant to flooding stress. Soybean germplasm and cultivars originating from other countries and grown in rotations with paddy rice potentially could have better flooding tolerance. Screen-house and field tests were conducted to determine variations in flooding tolerance among 21 soybean varieties from Southeast Asia. Flooding for two weeks at the R2 growth stage reduced grain yield under field conditions between $36 \%$ and $100 \%$ (all plants dead). However, plants that survived were, on the average, $13 \%$ taller than control plants. Tolerance to R2 flooding was associated with higher number of pods per plant and 100-grain weight. Growth response to flooding stress, as determined by plant height, was correlated with grain yield in all three environments. While there was no correlation in yield between field and screen-house tests, the flood tolerance ranking of the field test was correlated with the ranking of one screen-house test. Screen-house tests could distinguish tolerant from susceptible varieties based on plant survival and grain yield. Three varieties - VND2, Nam Vang and ATF15-1 - showed the best flooding tolerant responses under field and screen-house conditions. These lines provide new germplasm resources for the genetic improvement of flooding tolerance in soybean.
\end{abstract}

Keywords: Flooding tolerance, landraces, plant growth, grain yield, flooding, yield components.

\section{INTRODUCTION}

Flooding is a common environmental stress that injures plant growth and reduces soybean grain yield in the humid temperate region of the United States, where heavy rainfalls sometimes exceed surface and subsurface drainage capabilities [1-3]. In the Mississippi delta region, Asia, and other regions of the world where soybean crops are rotated with paddy rice, injuries due to flooding and flood irrigation are estimated to reduce overall soybean grain yield by as much as $25 \%$. According to Oosterhuis, et al. [4], flooding can reduce soybean yield $17 \%$ to $43 \%$ at the vegetative growth stage, and $50 \%$ to $56 \%$ at the reproductive stage. However, genetic variability for flooding tolerance exists among U.S. soybean cultivars [2]. In a three-year field screening of 360 soybean cultivars for flooding tolerance, Shannon et al. [5] reported a $40 \%$ yield reduction in the flood-tolerant group versus an $80 \%$ reduction in the flood-susceptible group.

Research on the late-planted flooding-sensitive soybean cultivar "Centennial" conducted in the southeastern United States indicates that flooding during the early vegetative (V2) and early reproductive (R1 to R3) stages is more damaging to grain yield than during other stages [6]. Yield loss

*Address correspondence to this author at the USDA-ARS, Soil Drainage Research Unit, Columbus, Ohio; Tel: 614-292-9806;

Fax: 614-292-9448; E-mail: tara.vantoai@ars.usda.gov primarily resulted from fewer pods per reproductive node. However, the variation in the effects of flooding on yield components of diverse soybean genotypes grown under different environments has not been fully investigated.

A great deal of research on flooding tolerance has been conducted in controlled greenhouse and growth chamber environments. Contrary to field flooding, which is detrimental to plant survival when lasting for two weeks or less [3,5], flooding in greenhouse and growth chamber studies usually does not result in plant death. In the greenhouse, soybean plants can produce aerenchyma and adventitious roots closer to the soil surface. The access and transportation of $\mathrm{O}_{2}$ to the deeper roots [7] allow soybean plants to adapt to flooding stress, survive, grow and reproduce. Bacanamwo and Purcell [8] reported that flooding treatment for up to 21 days at the V4-V6 growth stage under greenhouse conditions did not significantly reduce the shoot and root biomass of three soybean genotypes. According to Henshaw et al. [9-10] flooding for up to four weeks did not result in plant death in either tolerant or susceptible soybean genotypes. A quick, reproducible and seasonally-independent greenhouse or screenhouse test for flooding tolerance that simulates field test conditions would facilitate flooding research, including germplasm screening and testing transgenic soybean plants for flooding tolerance. For such greenhouse or screen-house tests to be useful, the correlation between responses to flooding in the field and responses in screen-house or greenhouse conditions needs to be validated. 
Because current U.S. soybean cultivars have a narrow genetic base [11-12], soybeans with better flooding tolerance may be found in cultivars and landraces from other countries. Soybeans in Southeast Asia are often cultivated under wet conditions and exhibit high tolerance to soil flooding [13]. In this study, we determined the responses of 21 soybean cultivars, landraces and plant introductions from Vietnam to flooding at the R2 growth stage under field and screen-house conditions. Comparative responses of soybean to flooding in the two environments were documented to verify if testing under screen-house conditions could simulate field tests. Plant growth and yield components after recovery from flooding stress were quantified and their correlation with grain yield analyzed.

\section{MATERIALS AND METHODS}

\section{Plant Materials}

The study was conducted with 21 soybean genotypes, including popular cultivars developed by traditional or mutation breeding, flood-tolerant landraces from Vietnam and Cambodia, and plant introductions (PI) from Australia, China, Japan and Taiwan (Table 1). These lines are determinate in growth habit with a life cycle from emergence to maturity of 75 to 80 days.

\section{Weather Conditions}

Weather conditions during the growing season are summarized in Table $\mathbf{2}$. The average temperature in the spring of

Table 1. Origin, Flower Color and Senescence of 21 Germplasm Lines Developed in, Native to, or Introduced into Vietnam Evaluated for Flooding Tolerance at Cuu Long Delta Rice Research Institute, Cantho, Vietnam in 2005 and 2006

\begin{tabular}{|c|c|c|c|c|}
\hline Variety & Origin & Flower Color & \multicolumn{2}{|c|}{ Maturity (d) $)^{\mathbf{a}}$} \\
\hline DNOM 3 & Landrace from Thonot district & purple & 86 & 76 \\
\hline DNOM 5 & Landrace from Thonot district & purple & 87 & 78 \\
\hline MTD676 & Cantho Univ. collection & purple & 84 & 75 \\
\hline ATF15-1 & Southern Agric. Inst. Collection. Selected from AFT15 (Australia) & purple & 88 & 79 \\
\hline DT93 & Agric Genetics Inst. From a cross of 821 (Vietnam) x 134 (Japan) & purple & 84 & 74 \\
\hline HL125 & Hung loc Agric. Res. Inst. collection. Selected from AGS-327B (Taiwan) & purple & 85 & 74 \\
\hline MSBR22 & PI from Australia & purple & 85 & 73 \\
\hline DT94 & Agric. Genetics Inst. From a cross of DT 84 x EC2004 & purple & 84 & 74 \\
\hline HL203 & Hung loc Agric Res Inst. collection. Selected from GC84058-18-4 (Taiwan) & purple & 84 & 76 \\
\hline 96113 & PI from Australia & purple & 90 & 76 \\
\hline MTD176 & Cantho Univ. collection. From a cross of ĐT76 x CES79-13 & purple & 87 & 75 \\
\hline VND2 & Inst Oilseed Crops collection. Selected from TN12 (China) & white & 83 & 76 \\
\hline СРAC368-7-6 & PI from Brazil & purple & 89 & 77 \\
\hline M 103 & $\begin{array}{l}\text { Released by Vietnam Agric. Sci. Inst. (VASI) \& Agric. Univ. No. } 1 \text { by mutation breeding of } \\
\text { V70 }\end{array}$ & purple & 85 & 72 \\
\hline
\end{tabular}

${ }^{a}$ Maturity was determined as days after sowing in the FD06 experiment; $\mathrm{CO}=$ control treatment; $\mathrm{FL}=$ flooding treatment. 
Table 2. Average Monthly Weather Data During the Screen-House and Field Flooding Tolerance Screening Experiments at the Cuu Long Delta Rice Research Institute, Cantho, Vietnam in 2005 and 2006

\begin{tabular}{|c|c|c|c|c|c|c|c|c|c|}
\hline & \multicolumn{9}{|c|}{ Month } \\
\hline Average temperature $\left({ }^{\circ} \mathrm{C}\right)$ & 27.0 & 28.4 & 28.0 & 27.6 & & & & & 27.8 \\
\hline Mean maximum daytime temperature $\left({ }^{\circ} \mathrm{C}\right)$ & 31.9 & 33.3 & 33.2 & 32.0 & & & & & 32.6 \\
\hline Total precipitation (mm) & 2.6 & 0.0 & 91.1 & 183.0 & & & & & 69.2 \\
\hline \multicolumn{10}{|l|}{ Screen-house Experiment SU05 } \\
\hline Average temperature $\left({ }^{\circ} \mathrm{C}\right)$ & & & & & 26.3 & 27.0 & 27.0 & 27.4 & 26.9 \\
\hline Mean maximum daytime temperature $\left({ }^{\circ} \mathrm{C}\right)$ & & & & & 30.4 & 30.9 & 30.7 & 31.1 & 30.8 \\
\hline \multicolumn{10}{|l|}{ Field Experiment SP06 } \\
\hline Average temperature $\left({ }^{\circ} \mathrm{C}\right)$ & 27.2 & 27.8 & 27.7 & 27.0 & & & & & 27.4 \\
\hline Mean maximum daytime temperature $\left({ }^{\circ} \mathrm{C}\right)$ & 31.9 & 32.7 & 32.7 & 31.3 & & & & & 32.2 \\
\hline Mean minimum nighttime temperature $\left({ }^{\circ} \mathrm{C}\right)$ & 24.1 & 24.6 & 24.5 & 24.6 & & & & & 24.5 \\
\hline Total precipitation (mm) & 106.3 & 51.3 & 256.5 & 222.4 & & & & & 153.9 \\
\hline
\end{tabular}

2005 and 2006 was $27.8{ }^{\circ} \mathrm{C}$ and $27.4{ }^{\circ} \mathrm{C}$, respectively. April and May are the hottest months in the Vietnam Cuu Long Delta. During these two months in 2005, the average maximum daytime temperature exceeded $33{ }^{\circ} \mathrm{C}$. The spring of 2005 was much drier than normal with almost no rain in March and April. In the spring of 2006, when soybean plants were tested under field conditions, rainfall was more normal and more evenly distributed. The average rainfall was 153.9 $\mathrm{mm}$ per month from March to June. The summer average temperature of $26.9{ }^{\circ} \mathrm{C}$ did not differ much from the spring average temperature of $27.8{ }^{\circ} \mathrm{C}$, but the summer average maximum temperature was about two degrees lower (30.8 $\left.{ }^{\circ} \mathrm{C}\right)$ than the spring average maximum temperature $\left(32.4{ }^{\circ} \mathrm{C}\right)$. Summer is also a wet season in the Cuu Long Delta region, with an average rainfall of $243.5 \mathrm{~mm}$ per month.

\section{Screen-House Experiments}

Plants of each of the 21 soybean genotypes were grown in the screen-house of the Cuu Long Delta Rice Research Institute, Cantho, Vietnam in the spring of 2005 (SP05 experiment) and summer of 2005 (SU05 experiment). The screen-house was covered with chicken wire on all four sides and the roof such that the plants were exposed to ambient environmental conditions while minimizing damage by rodents and other animals. In the SP05 study, two seeds each were planted in $15-\mathrm{cm}$ pots filled with top-soil. After emergence, seedlings were thinned to one plant per pot. The experiment layout was a randomized block design with five replicates. The SU05 study was similar, with the exception that four seeds each were planted in 22 -cm pots. After emer- gence, seedlings were thinned to two plants per pot. Each treatment was replicated three times for each genotype.

Flooding treatment was imposed at the $\mathrm{R} 2$ growth stage [14] for two weeks by placing individual pots in $30-\mathrm{cm}$ buckets and adding water to $5 \mathrm{~cm}$ above the soil surface. Plants in the control treatment were watered to maintain stress-free normal growth. At the end of the flooding treatment, pots were drained and plants permitted to recover and grow to maturity. Grain yield in grams per plant, plant height, number of reproductive branches, number of reproductive nodes, number of three-seed pods per plant, total number of pods per plant, and 100-grain weight were measured on individual plants.

\section{Field Experiment}

The field experiment (FD06) was conducted in the spring of 2006 on two adjacent fields at the Cuu Long Delta Rice Research Institute, Cantho, Vietnam (latitude $10^{\circ} 05^{\prime} \mathrm{N}$ and longitude $105^{\circ} 42^{\prime}$ E) using the same 21 genotypes. The soil type is Eutric Gleysol, alluvial clayey silt with $\mathrm{pH}$ levels between 5.6 and 5.8. The control field had drainage ditches around and between replications, whereas the flooded field was surrounded by dikes. The genotypes were planted in a randomized complete block design with three replications in each field. Plots consisted of six 3.0 meter long rows separated by 0.4 meter. Seeds were hand-planted in the six rows on 3 March 2006 at a density of four seeds per hill, spaced $20 \mathrm{~cm}$ apart within each row. After two weeks, seedlings were thinned to two plants per hill. Fertilizer was applied at the rate of $60-60-30 \mathrm{~kg} \mathrm{NPK} / \mathrm{ha}$. Weeds were controlled 
though herbicide application and manual weeding. Pesticides for diseases and insect control were applied as needed.

The flooding treatment was imposed by pumping water to a depth of $10-15 \mathrm{~cm}$ above the soil surface when the majority of soybean genotypes reached the R2 growth stage. Additional water was added every two days to maintain flooding at the same level. After two weeks, flooded plots were drained. The plants were then watered in a similar manner to the control - as needed until maturity. At harvest, data were recorded for plant height, number of pods per hill, 100-grain weight and grain yield. Plant height was determined based on five randomly selected plants per plot. The pod number was counted from five randomly selected hills per plot. Grains were threshed by hand and grain yield was determined on a per plot basis.

\section{Statistical Analysis}

Analyses of variance were conducted using PROC GLM of SAS ${ }^{\circledR}$ PC for Windows Version 9.1.3 (SAS Institute Inc., Cary, NC) to compute the mean and examine varietal differences in plant height, grain yield and other yield parameters.

A dependent variable "percent reduction from flooding in relation to the control treatment" was calculated according to the formula: Yield reduction $=($ control-flooding $) /$ control*100. To identify flooding-tolerant genotypes, the yield reduction due to flooding was ranked in each of the three different experiments using the PROC RANK. The most tolerant (lowest reduction in yield) was assigned the score $=1$ and the least tolerant $=21$. Pearson correlation analyses were conducted using the PROC CORR.

\section{RESULTS}

Analyses of variance showed that plant height and grain yield were significantly different among the 21 varieties in both screen-house and field tests. Flooding significantly affected both the height and grain yield of soybeans in all three SP05, SU05 and FD06 experiments. The interaction of flooding and variety was also highly significant in all three experiments.

\section{Yield Response of Soybean Germplasm from Southeast Asia to Flooding}

In the SP05 experiment, control grain yield of the 21 soybean varieties ranged from 7.6 to $17.7 \mathrm{~g} / \mathrm{plant}$ (Fig. 1A). Flooding reduced grain yield by an average of $52.5 \%$ with the range in yield reduction from less than $1 \%$ to $100 \%$ (all plants dead) depending on the varieties (Table 3). Control grain yield of the SU05 experiment ranged from $9.8 \mathrm{~g} / \mathrm{plant}$ to $18.5 \mathrm{~g} /$ plant (Fig. 1B). Flooding for two weeks reduced grain yield by an average of $62.2 \%$ (Table 3 ). The average control grain yield in the field experiment (FD06) was 566.5 $\mathrm{g} / \mathrm{plot}$ with the range from $264.5 \mathrm{~g} / \mathrm{plot}$ to $897.5 \mathrm{~g} / \mathrm{plot}$ (Fig. 1C). After two weeks of flooding, the average yield was $147.5 \mathrm{~g} / \mathrm{plot}$, a $73.9 \%$ reduction compared to control yield (Table 3).

When varieties were ranked based on yield reduction due to flooding, the ranking between the two screen-house experiments, SP05 and SU05, was significantly correlated $(\mathrm{r}=0.69 ; \mathrm{p}<0.05)$. The ranking between the FD06 and SU05 was also significantly correlated $(r=0.52 ; \mathrm{p}<0.05)$. However, the ranking between the FD06 and SP05 experiment was not significant $(\mathrm{r}=0.32)$. The three varieties which were consistently in the top five most tolerant of all three FD06, SP05 and SU05 experiments were VND2, NamVang, and ATF151. Two weeks of flooding in the field (FD06 experiment) reduced grain yield of these tolerant varieties by $43.4 \%$ as compared to the $74.0 \%$ average reduction of all the 21 varieties. DNOM1 was the variety which consistently showed a high flood-susceptible ranking in all three experiments. Two weeks of flooding in SP05, SU05 and FD06 experiments reduced seed yield of this variety by $80.2 \%, 75.1 \%$, and $92.0 \%$, respectively (Table 3 ).

\section{Plant Survival and Growth of Soybean Germplasm from Southeast Asia in Response to Flooding}

All control plants in all three experiments survived. Flooding for two weeks reduced plant survival to $51.8 \%$, $69.1 \%$ and $58.9 \%$ in the SP05, SU05 and FD06 experiments, respectively. Flooding also accelerated the average maturity of the plants by 11 days. The early senescence ranged from eight days in BR5-1 to 17 days in the flood-susceptible DNOM1 variety (Table 1).

In the SP05 experiment, the plant height of 21 soybean varieties in the control treatment ranged from 21.6 to 69.4 $\mathrm{cm}$ with an average of $47.3 \mathrm{~cm}$. Flooding reduced this average height to $30.3 \mathrm{~cm}$. The average control plant height of the SU05 was $54.7 \mathrm{~cm}$. Flooding reduced average plant height by $27.4 \%$ to $39.6 \mathrm{~cm}$. In the FD06 experiment, plants grew $13.0 \%$ taller in response to flooding - from an average of $44.6 \mathrm{~cm}$ in the control treatment to $50.4 \mathrm{~cm}$ in the flooding treatment (Table 4). Nam Vang and VND2 were the only varieties that grew tall in response to flooding in all three experiments.

\section{Correlation Between Grain Yield and Other Traits in Response to Flooding Stress}

Flooded grain yield was highly correlated with plant survival in all three experiments (Table 5). The correlation coefficients ranged from 0.96 in the SP05 to 0.64 and 0.78 in the SU05, FD06 experiments, respectively. In all three experiments, grain yield was also correlated with plant height. The correlation coefficients for the control treatment were 0.53 $(\mathrm{p} \leq 0.01)$ in the SP05 experiment, $0.47(\mathrm{p} \leq 0.05)$ in the SU05 and $0.67(p<0.001)$ in the FD06 experiment. The correlation coefficients in the flooding treatment were 0.90 $(\mathrm{p}<0.0001), 0.59(\mathrm{p}<0.01)$ and $0.45(\mathrm{p}<0.05)$ in the SP05, SU05 and FD06 experiments, respectively.

Among the yield components, grain yield was consistently correlated with the total pod numbers in both control and flooding treatments of all three experiments. The correlation coefficients in the control treatment were 0.42 $(\mathrm{p}<0.05), 0.45(\mathrm{p}<0.05)$ and $0.77(\mathrm{p}<0.0001)$ for the SP05, SU05 and FD06 treatments, respectively. For the flooding treatment, the correlation coefficients were $0.91(\mathrm{p}<0,0001)$, $0.47(\mathrm{p}<0.05)$, and $0.67(\mathrm{p}<0.001)$ in the three experiments, respectively. Grain yield was also correlated with the 100grain weight in the flooding treatment with the correlation coefficients of 0.93 ( $\mathrm{p}<0.0001), 0.77$ ( $\mathrm{p}<0.0001)$, and 0.50 $(\mathrm{p}<0.05)$ for the three experiments, respectively. No correlation between grain yield and 100-grain weight was detected 

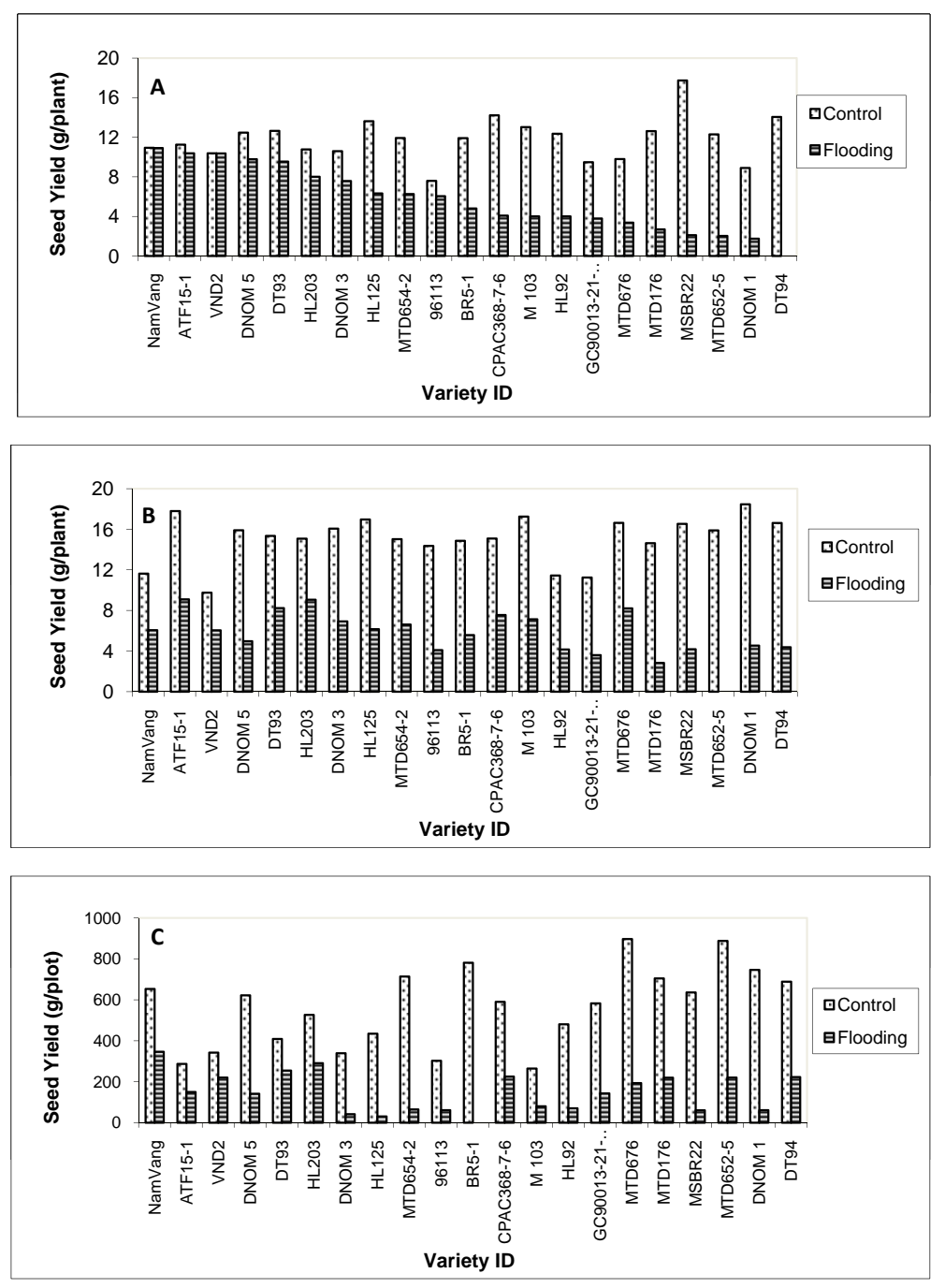

Fig. (1). Seed yield of control and flooding treatments of the spring 2005 (SP05) experiment (A), summer 2005 (SU05) experiment (B), and field 2006 (FD06) experiment (C).

Table 3. Yield Reduction and Ranking of Flooding Tolerance, Calculated as Described in the Materials and Methods Section, of the 21 Soybean Varieties in the Spring 2005 (SP05) and Summer 2005 (SU05) Screen-House and Field 2006 (FD06) Experiments at Cuu Long Rice Research Institute, Cantho, Vietnam

\begin{tabular}{|c|c|c|c|c|c|c|}
\hline \multirow{3}{*}{ Variety } & \multicolumn{6}{|c|}{ Experiment } \\
\hline & Yield Reduction & Rank & Yield Reduction & Rank & Yield Reduction & Rank \\
\hline & $(\%)$ & & $(\%)$ & & $(\%)$ & \\
\hline DNOM 1 & 80.2 & 18.0 & 75.1 & 18.0 & 92.0 & 19.0 \\
\hline DNOM 5 & 20.9 & 6.0 & 68.7 & 14.0 & 77.2 & 12.0 \\
\hline MTD652-5 & 83.0 & 19.0 & 100.0 & 21.0 & 75.2 & 11.0 \\
\hline MTD676 & 65.5 & 13.0 & 50.6 & 6.0 & 78.4 & 13.0 \\
\hline ATF15-1 & 7.8 & 3.0 & 49.0 & 3.0 & 47.6 & 3.0 \\
\hline
\end{tabular}


Table 3. contd....

\begin{tabular}{|c|c|c|c|c|c|c|}
\hline \multirow{4}{*}{ Variety } & \multicolumn{6}{|c|}{ Experiment } \\
\hline & \multicolumn{2}{|c|}{ SP05 } & \multicolumn{2}{|c|}{ SU05 } & \multicolumn{2}{|c|}{ FD06 } \\
\hline & Yield Reduction & Rank & Yield Reduction & Rank & Yield Reduction & Rank \\
\hline & $(\%)$ & & $(\%)$ & & $(\%)$ & \\
\hline Nam Vang & 0.2 & 1.5 & 47.9 & 2.0 & 63.3 & 7.0 \\
\hline BR5-1 & 18.5 & 4.0 & 62.4 & 11.0 & 100.0 & 21.0 \\
\hline HL125 & 54.3 & 11.0 & 59.7 & 4.0 & 93.1 & 20.0 \\
\hline MSBR22 & 88.2 & 20.0 & 74.7 & 17.0 & 84.3 & 15.0 \\
\hline DT94 & 100.0 & 21.0 & 73.6 & 16.0 & 67.7 & 8.0 \\
\hline HL203 & 25.6 & 8.0 & 81.5 & 20.0 & 45.0 & 2.0 \\
\hline 96113 & 20.3 & 5.0 & 71.5 & 15.0 & 80.2 & 14.0 \\
\hline MTD176 & 78.8 & 17.0 & 80.6 & 19.0 & 68.8 & 9.0 \\
\hline VND2 & 0.2 & 1.5 & 37.9 & 1.0 & 59.1 & 5.0 \\
\hline HL92 & 67.6 & 14.0 & 74.4 & 10.0 & 85.4 & 16.0 \\
\hline GC90013-21-15-10 & 59.9 & 12.0 & 68.0 & 13.0 & 37.6 & 1.0 \\
\hline MTD654-2 & 47.5 & 10.0 & 56.0 & 7.0 & 90.9 & 18.0 \\
\hline СРАC368-7-6 & 71.3 & 16.0 & 49.9 & 5.0 & 61.9 & 6.0 \\
\hline M 103 & 69.1 & 15.0 & 58.6 & 9.0 & 69.8 & 10.0 \\
\hline
\end{tabular}

Table 4. Plant Height of 21 Soybean Varieties of Control (CO) and Flooding (FL) Treatments in the Spring 2005 (SP05) and Summer 2005 (SU05) Screen-House, and Field 2006 (FD06) Experiments at Cuu Long Rice Research Institute, Cantho, Vietnam

\begin{tabular}{|c|c|c|c|c|c|c|}
\hline \multirow[b]{2}{*}{ Variety } & \multicolumn{6}{|c|}{ Plant Height (cm) } \\
\hline & \multicolumn{2}{|c|}{ SP05 } & \multicolumn{2}{|c|}{ SU05 } & \multicolumn{2}{|c|}{ FD06 } \\
\hline DNOM 1 & 48.4 & 15.4 & 64.2 & 72.9 & 53.4 & 58.5 \\
\hline DNOM 3 & 37.2 & 32.6 & 40.2 & 32.7 & 38.4 & 52.3 \\
\hline MTD652-5 & 69.4 & 15.6 & 83.6 & 0.0 & 55.7 & 74.0 \\
\hline MTD676 & 51.0 & 26.2 & 68.6 & 43.3 & 45.3 & 57.3 \\
\hline ATF15-1 & 47.2 & 45.6 & 48.8 & 46.8 & 36.0 & 46.1 \\
\hline HL125 & 52.8 & 35.4 & 52.2 & 53.5 & 46.2 & 45.9 \\
\hline MSBR22 & 51.8 & 12.4 & 57.3 & 37.1 & 44.5 & 52.0 \\
\hline DT94 & 44.6 & 0.0 & 51.7 & 44.7 & 41.4 & 46.7 \\
\hline HL203 & 34.6 & 38.6 & 54.3 & 49.7 & 40.6 & 47.5 \\
\hline 96113 & 21.6 & 23.4 & 42.3 & 29.8 & 32.1 & 34.7 \\
\hline
\end{tabular}


Table 4. contd....

\begin{tabular}{|c|c|c|c|c|c|c|}
\hline \multirow{2}{*}{$\begin{array}{l}\text { Variety } \\
\text { MTD176 }\end{array}$} & \multicolumn{6}{|c|}{ Plant Height (cm) } \\
\hline & \multicolumn{2}{|c|}{ SP05 } & \multicolumn{2}{|c|}{ SU05 } & \multicolumn{2}{|c|}{ FD06 } \\
\hline VND2 & 25.8 & 37.2 & 23.2 & 26.8 & 30.3 & 35.5 \\
\hline HL92 & 48.8 & 23.4 & 55.0 & 41.1 & 40.9 & 42.6 \\
\hline MTD654-2 & 62.8 & 48.4 & 70.5 & 48.3 & 66.6 & 68.9 \\
\hline СРAC368-7-6 & 55.0 & 25.8 & 47.4 & 30.5 & 37.1 & 49.7 \\
\hline M 103 & 49.6 & 21.0 & 53.7 & 44.8 & 37.7 & 42.7 \\
\hline Mean & 47.3 & 30.3 & 54.6 & 39.6 & 44.6 & 50.5 \\
\hline
\end{tabular}

Table 5. Correlation Coefficients of Seed Yield with Plant Height, Plant Survival, and Yield Components in Control (CO) and Flooding (FL) Treatments of the Spring 2005 (SP05) and Summer 2005 (SU05) Screen-House, and Field 2006 (FD06) Experiments at Cuu Long Delta Rice Research Institute, Cantho, Vietnam

\begin{tabular}{|c|c|c|c|c|c|c|c|c|c|c|}
\hline & & Plant & Plant & Reprod. & Reprod. & 1-seed & 2-seed & 3-seed & Total & 100-seed \\
\hline & Treatment & Survival & Height & Branches & Nodes & Pods & Pods & Pods & Pods & Weight \\
\hline \multicolumn{11}{|l|}{ SP05 } \\
\hline Yield & $\mathrm{CO}$ & & $0.53 * *$ & 0.26 & 0.31 & $-0.47 *$ & 0.30 & $0.82 * * * *$ & $0.42 *$ & 0.37 \\
\hline Yield & FL & $0.96 * * * *$ & $0.90^{* * * * *}$ & $0.79 * * * *$ & $0.96 * * * *$ & 0.30 & $0.78^{* * * * *}$ & $0.92 * * * *$ & $0.91 * * * *$ & $0.93 * * * *$ \\
\hline \multicolumn{11}{|l|}{ SU05 } \\
\hline Yield & $\mathrm{CO}$ & & $0.47 *$ & 0.35 & 0.72 & -0.03 & 0.18 & 0.22 & $0.45^{*}$ & 0.37 \\
\hline Yield & FL & $0.64 * * * *$ & $0.59 * *$ & $0.56^{* * *}$ & $0.61 * *$ & 0.35 & 0.33 & 0.07 & $0.47^{*}$ & $0.77 * * * *$ \\
\hline \multicolumn{11}{|l|}{ FD06 } \\
\hline Yield & $\mathrm{CO}$ & & $0.67 * * *$ & & & & & & $0.77 * * * *$ & 0.21 \\
\hline Yield & FL & $0.78 * * * *$ & $0.40 *$ & & & & & & $0.67 * * *$ & $0.50 *$ \\
\hline
\end{tabular}

$*, * *, * * *, * * * *$ significant at the $0.05,0.01,0.001$, and 0.0001 levels of probability, respectively

in the control treatment in any of the three experiments. In the SP05 and SU05 experiments, grain yield of the flooding treatment was correlated with the number of reproductive branches $(r=0.79, p<0.0001$ and $0.56, p<0.01$, respectively), and number of reproductive nodes $(\mathrm{r}=0.96, \mathrm{p}<0.00001$ and $0.61, \mathrm{p}<0.01$, respectively).

\section{Correlation Between Field and Screen House Tests}

The correlation between the field experiment FD06 and screen-house experiments SP05 and SU05 was significant only for control plant height (Table 6). The correlation coefficients between the FD06 and SP05 experiments were 0.54 $(\mathrm{p}<0.01)$ and between the FD06 and SU05 were 0.74 $(\mathrm{p}<0.0001)$. Flooded plant height was not correlated between field and greenhouse experiments. Grain yield was also not correlated between field and screen-house tests of either treatment (Table 6).

\section{DISCUSSION}

Flooding stress in this study consisted of subjecting plants to water levels from $5 \mathrm{~cm}$ (screen-house experiments) to $10-15 \mathrm{~cm}$ (field experiment) above the soil surface. As such, the flooding treatment was more than just soilwaterlogging [2] but not as severe as complete submergence stress [3]. We have identified three soybean varieties which showed consistent tolerance to flooding stress under both screen-house and field tests. Of these, Nam Vang is a landrace collected from Cambodia; VND2, a germplasm in the collection of the Institute of Oilseed Crops originated from China; and ATF15-1, a germplasm in the collection of the Southern Agricultural Institute originated from Australia. The flooding tolerance of the seminal lines from which VND2 and ATF15 were selected is not known.

Flooding tolerance can be defined as minimal or no yield loss due to flooding [15]. In both screen-house and field 
Table 6. Correlation Coefficients of Plant Height and Seed Yield Between Field (FD06) and Screen House (SP05 and SU05) Experiments at Cuu Long Delta Rice Research Institute, Cantho, Vietnam in 2005 and 2006. CO = Control Treatment, FL = Flooding Treatment

\begin{tabular}{|l|l|l|l|l|}
\hline \multicolumn{6}{|l|}{ Correlation in plant height between field and screen-house tests } \\
\hline Trait $\mathbf{1}$ & CO Height FD06 & CO Height FD06 & FL Height FD06 & FL Height FD06 \\
\hline Trait 2 & CO Height SP05 & CO Height SU05 & FL Height SP05 & FL Height SU05 \\
\hline $\mathrm{R}$ & $0.54^{* *}$ & $0.74 * * *$ & -0.27 & -0.35 \\
\hline Correlation in seed yield between field and screen-house tests & CO Yield-FD06 & FL Yield FD06 & FL Yield FD06 \\
\hline Trait $\mathbf{1}$ & CO Yield FD06 & CO Yield SU05 & FL Yield SP05 & FL Height SU05 \\
\hline Trait 2 & CO Yield SP05 & 0.11 & 0.26 & 0.13 \\
\hline $\mathrm{R}$ & 0.1 &
\end{tabular}

$*, * *, * * *$ significant at the $0.05,0.01$, and 0.001 , levels of probability, respectively.

tests, control yields of the three tolerant varieties, which showed minimal yield loss due to flooding, were lower than the average control yield of all the varieties (Table 3 ). The results indicate that the reduction in yield due to flooding may be related to control yield: varieties with higher yield under control conditions were more suppressed under flooding conditions.

Flooding induces plant senescence in tobacco and tomato [16], sunflower [17], carrot [18], barley [19], peas [20], wheat [21, 22], and maize [23]. VanToai et al. [24] also reported that field flooding for two weeks at the R1 stage hastened soybean maturity from six to eight days. In this study, two weeks of field flooding at the R2 stage hastened the average maturity of the 21 varieties by 11 days (Table 1). Early senescence, however, was only accelerated by eight days among the three most tolerant varieties, or three days later than the overall average.

Although high grain yield is the ultimate criterion of flooding tolerance for crop producers, plant growth, including plant height, root, and shoot biomass, has also been frequently used as a determinant of flooding tolerance $[9,10$, 25-26]. Two-week flooding at the R1 growth stage has been reported to reduce plant height of two soybean recombinant inbred populations and their parental lines from 16 to $28 \%$ [24]. However, growth responses of soybean to flooding were highly dependent on the plant growth stage when flooding occurred [6]. In this study, flooding for two weeks at the R2 stage reduced the average plant height in both screen house experiments; but flooded plants grew taller than control plants in the field experiment. The reason was not clear since the control plants of the field experiment were irrigated regularly and exhibited no indication of drought or any other stress. This study established the correlation between flooded plant height and flooded grain yield in both field and screen-house tests. Plant height, therefore, is a good indicator of tolerance of soybean to flooding at early reproductive stage.

In the greenhouse study by Linkemer et al. [6], flooding for seven days at the R3 stage reduced grain yield by $93 \%$ through reducing grain size, number of seeds per pod as well as number of pods per reproductive node. Both screen-house and field tests in our study indicated that flooded grain yield was correlated with higher number of pods per hill (or per plant), as well as the 100-grain weight. The largest influence on grain yield in both field and screen-house tests was the number of plants which survived flooding stress.

Contrary to reports of greenhouse-grown soybean plants surviving flood conditions, screen-house tests in this study indicated that two weeks of flooding caused up to $100 \%$ plant death in susceptible varieties. The variation in results between this screen-house test and other greenhouse studies in which no plant death occurred could be due to two factors that affect plant growth: (i) the medium in which soybeans were grown in this study was non-fumigated field soil as compared to soil-less growth mixtures or sterilized soil mixture in other studies $[7,8]$, and injury to flood susceptible plants in this screen-house study could have been disease related. Phytophthora root and stem rot caused by Phytophthora sojae M.J. Kaufmann \& J.W. Gerdermann is a common soybean disease in wet soil. (ii) the temperature and light intensity in our screen-house tests were much higher than the temperature and light of other greenhouse studies (Table 2). High temperature and high irradiance have been shown to increase plant injury to flooding [27, 28].

\section{CONCLUSIONS}

The present study of 21 soybean varieties grown under three conditions demonstrated that screen-house tests with non-fumigated field soil can provide a good model for flooding tolerance testing when plant growth is used as a criterion. It also indicates that screen-house tests, while not completely duplicating field tests, can distinguish tolerant varieties from susceptible varieties. Flood-tolerant varieties survived better, grew taller, produced more pods/plants and heavier seed weight than susceptible varieties in both screen-house and field tests. The three most tolerant varieties identified in this study --VND2, Nam Vang and ATF15-1-- could provide new germplasm resources for genetic improvement of tolerance of soybean to flooding up to $5-15 \mathrm{~cm}$ above the soil surface. Tolerance of these varieties to soil waterlogging or complete submergence will remain to be determined.

\section{ACKNOWLEDGEMENT}

This study was supported by a grant from the USDA Foreign Agriculture Service for international collaboration between Vietnam and the United States. 
We would like to thank Dr. Tran Dinh Long, President of Vietnamese Seed Association and Vice Chairman of Scientific Council of Vietnam Academy of Agricultural Sciences for information about the origin of the varieties in this study and Ms Debra Gamble for critical reading and editing of the manuscript.

\section{LIST OF ABBREVIATIONS}

$\begin{array}{ll}\mathrm{CO} & =\text { Control } \\ \mathrm{FD} 06 & =\text { Field } 2006 \text { experiment } \\ \mathrm{FL} & =\text { Flooding } \\ \text { SP05 } & =\text { Spring } 2005 \text { screen-house experiment } \\ \text { SU05 } & =\text { Summer } 2005 \text { screen-house experiment }\end{array}$

\section{REFERENCES}

[1] Fausey NR. Subirrigation/Drainage systems for water table management in the Midwest. Proceedings of the International Irrigation Exposition and Technical Conference, Atlanta GA 1994; pp. 242-6.

[2] VanToai TT, Beuerlein JE, Schmitthenner AF, St. Martin SK. Genetic variability for flooding tolerance in soybeans. Crop Sci 1994; 34(4): 1112-5.

[3] Sullivan M, VanToai TT, Fausey N, Beuerlein J, Parkinson R, Soboyejo A. Evaluating on-farm flooding impacts on soybean. Crop Sci 2001; 41(1): 93-100.

[4] Oosterhuis DM, Scott HD, Hampton RE, Wullschleter SD. Physiological response of two soybean [Glycine max, L. Merr] cultivars to short-term flooding. Environ Exp Bot 1990; 30(1): 85-92.

[5] Shannon JG, Stevens WE, Wiebold WJ, McGraw RL, Sleper DA, Nguyen HT. Breeding soybeans for improved tolerance to flooding. Procedure of 30th Soybean Research Conference, American Seed Trade Association, Chicago, IL, December 7th, 2005.

[6] Linkemer G, Beard JE, Musgrave ME. Waterlogging effects on growth and yield components in late-planted soybean. Crop Sci 1998; 38(6): 1576-84.

[7] Bacanamwo M, Purcell LC. Soybean root morphological and anatomical traits associated with acclimation to flooding. Crop Sci 1999; 39(1): 143-9.

[8] Bacanamwo M, Purcell L. Soybean dry matter and $\mathrm{N}$ accumulation responses to flooding stress, $\mathrm{N}$ sources and hypoxia. J Exp Bot 1999; 50(334): 689-96.

[9] Henshaw TL, Gilbert RA, Scholberg JMS, Sinclair TR. Soya bean (Glycine max L. Merr.) genotype response to early-season flooding: II. Aboveground growth and biomass. J Agron Crop Sci 2007; 193(3): 189-97.
[10] Henshaw TL, Gilbert RA, Scholberg JMS, Sinclair TR. Soya bean (Glycine $\max$ L. Merr.) genotype response to early-season flooding: I. root and nodule development. J Agron Crop Sci 2007; 193(3): 177-88.

[11] Gizlice Z, Carter Jr. TE, Burton JW. Genetic base for North American public soybean cultivars released between 1947 and 1988. Crop Sci 1994; 34(5): 1143-51.

[12] Gizlice Z., Carter Jr. TE, Burton JW. Genetic diversity patterns in North American public soybean cultivars based on coefficient of parentage. Crop Sci 1996; 36(3): 753-65.

[13] VanToai TT, Nurjani N. Screening for flooding tolerance of soybean. Soybean Genet Newslett 1996; 23: 210-13

[14] Fehr WR, Caviness CE. Stages of soybean development. Iowa Agriculture Experiment Station Special Report 801977.

[15] Roiselle AA, Hamblin J. Theoretical aspects of selection for yield in stress and non-stress environments. Crop Sci 1981; 21(6): 943-6.

[16] Kramer PJ. Causes of injury to plants resulting from flooding of the soil. Plant Physiol 1951; 26(4): 722-36.

[17] Kawase M. Role of ethylene in induction of flooding damage in sunflower. Physiol Plant 1974; 31(1): 29-38.

[18] Olymbios CM, Schwabe WW. Effects of aeration and soil compaction on growth of the carrot, Daucus carota L. J Hort Sci 1977; 52(4): 485-500.

[19] Drew MC, Sisworo EJ. Early effects of flooding on nitrogen deficiency and leaf chlorosis in barley. New Phytol 1977; 79(3): 56771 .

[20] Jackson MB. Rapid injury to peas by soil waterlogging. J Sci Food Agric 1979; 30(2): 143-52

[21] Trought MCT, Drew MC. The development of waterlogging damage in wheat seedlings (Triticum aestivum L.). I. Shoot and root growth in relation to changes in the concentrations of dissolved gases and solutes in the soil solution. Plant Soil 1980; 54(1): 77-94.

[22] Boru GM, van Ginkel Kronstad WE, Boersma L. Expression and inheritance of tolerance to waterlogging stress in wheat. Euphytica 2001; 117(2): 91-98

[23] Wenkert W, Fausey NR, Watters HD. Flooding responses in Zea mays L. Plant Soil 1981; 62(3): 351-66.

[24] VanToai TT, St. Martin SK, Chase K, et al. Identification of a QTL associated with tolerance of soybean to soil waterlogging. Crop Sci 2001; 41(4): 1247-52.

[25] Daugherty CJ, Musgrave ME. Characterization of populations of rapid-cycling Brassica rapa L. selected for differential waterlogging tolerance. J Exp Bot 1994; 45(272): 385-92.

[26] Huynh L, VanToai TT, Streeter J, Banowetz G. Regulation of flooding tolerance of SAG12: ipt Arabidopsis plants by cytokinin. J Exp Bot 2005; 56(415): 1397-1407.

[27] Barta AL, Sulc RM. Interaction between waterlogging injury and irradiance level in alfalfa. Crop Sci 2002; 42(5): 1529-34.

[28] Cameron DG. Lucerne in wet soils: The effect of stage of regrowth, cultivar, air temperature, and root temperature. Australia J Agric Res 1973; 24(6): 851-61. 